\title{
The expression and functional characterization associated with cell apoptosis and proteomic analysis of the novel gene MLAA-34 in U937 cells
}

\author{
WEN-JUAN ZHANG, WANG-GANG ZHANG, PENG-YU ZHANG, \\ XING-MEI CAO, AI-LI HE, YIN-XIA CHEN and LIU-FANG GU \\ Department of Clinical Hematology, Affiliated No. 2 Hospital, Xi'an Jiaotong University \\ College of Medicine, Xi'an, Shaanxi 710004, P.R. China
}

Received August 12, 2012; Accepted September 25, 2012

DOI: 10.3892/or.2012.2129

\begin{abstract}
MLAA-34 is a novel acute monocytic leukemia (M5)-associated antigen (MLAA) that plays a role in the apoptosis of U937 cells. However, the expression and molecular mechanism of MLAA-34 in U937 cells remain largely unclear. Here, we utilized three strategies to gain insight into the expression and molecular functions of MLAA-34 and to identify its interacting proteins and pathways involved in the fine-tuning of the MLAA-34 response. Western blot analysis was performed to assess the expression of MLAA-34 in 41 cell lines and five mixed cell types, which revealed that MLAA-34 is most strongly expressed in U937 cells. Immunostaining indicated that MLAA-34 is localized in the cytoplasm and cell membrane. Furthermore, lentivirus-mediated overexpression of MLAA-34 in the U937 cell line led to significant suppression of apoptosis and increased the potential of tumorigenicity. Co-immunoprecipitation (Co-IP), shotgun and bioinformatic analysis identified 256 proteins and 225 of them were annotated by gene ontology categories. This analysis revealed 71 proteins involved in cell apoptosis or proliferation of biological processes and signaling pathways. Moreover, the effect of MLAA-34 apoptosis may be through interaction with the Ras, Wnt, calcium and chemokine signaling pathways and thirteen of the annotated proteins may interact with MLAA-34 and participate in carcinogenesis directly. This study provides a basis for a better understanding of the molecular mechanism and proteomics in the inhibition of apoptosis by MLAA-34 in U937 cells and indicates that MLAA-34 may be a potential candidate for the early diagnosis and therapeutic application of M5.
\end{abstract}

Correspondence to: Professor Wang-Gang Zhang, Department of Clinical Hematology, Affiliated No. 2 Hospital, Xi'an Jiaotong University College of Medicine, 157 West 5 Road, Xi'an, Shaanxi 710004, P.R. China

E-mail: juner0705@163.com

Key words: MLAA-34, U937, acute monocytic leukemia, lentivirus, anti-apoptosis, proteomics

\section{Introduction}

Leukemia is the leading cause of mortality worldwide in patients with malignant tumors under the age of 35 years. Patients with acute myeloid leukemia (AML) who have relapsed or are refractory to conventional chemotherapy have a poorer prognosis and response to chemotherapy than those with de novo AML, which remains a formidable therapeutic challenge even with the introduction of several new therapeutic strategies (1-3). M5 is largely incurable with high relapse rates, infiltration and a median remission duration of only six months, approximately (4). Moreover, M5 has been reported to have a worse prognosis than other subtypes of AML (5). Thus, a vaccine or a new drug against M5 is required as a strategic tool for the control of this disease, but none are currently available for practical use.

The MLAA-34 gene (GenBank no. AY288977.2) has been confirmed to be a novel splice variant of CAB39L (calcium binding protein 39-like). MLAA-34 was first discovered in M5 in an effort to identify monocytic leukemia-associated antigens by serologic analysis of a recombinant cDNA expression library (SEREX) that reacted exclusively with sera from allogeneic leukemia patients but not with normal donor sera $(6,7)$. The $1671 \mathrm{~kb}$ gene is located on $13 q 14.2$ and was initially cloned in our laboratory from U937 cells (7). CAB39L has three alternative transcripts and has been predicted to encode a 337 aa protein. The three alternative transcripts of CAB39L have been recognized to encode the same protein, differing only in their 5' untranslated regions [GenBank nos. BC010993 (1482 bp), BX647518 (2371 bp) and AY288977.2].

In our previous study, MLAA-34 and CAB39L were identified with RNA interference (RNAi) in the U937 cell line as novel anti-apoptotic factors that are closely related to carcinogenesis or progression of M5 (7). Clinical research has shown that MLAA-34 mRNA expression is upregulated in refractory/ relapsed M5 patients compared with newly diagnosed, healthy donors and AML patients in complete remission; high expression of MLAA-34 is more prominent in the M5 subtype than in other AML patients; MLAA-34 overexpression has been found to be associated with unfavorable clinical features at diagnosis and has been shown to be an independent prognostic factor (8). 
However, for MLAA-34, there are no exact reports regarding its cellular localization and expression in manifold cell lines; the anti-apoptotic mechanism of MLAA-34 remains unclear.

The purpose of this study was to conduct an in-depth search for the expression and anti-apoptotic mechanism of MLAA-34 through the lentivirus-mediated overexpression in the U937 cell line, and to then apply proteomics to identify its correlated proteins or pathways that might perform functions important for the apoptosis and proliferation of U937 cells.

\section{Materials and methods}

Cell culture. U937, HL60, K562, RPMI-8226, HepG2, Hep3B, MHCC97-H, RC-K8, SGC-7901, Eca109, BGC823, MKN45, GES-1, BxPC-3, A375, T24, HUVEC, BMSCs, LO2, HeLa, 293T, 293, RD, RT4, 5637, EJ, UM-UC-3, 2537, J82, Tsu-Prl, MAH, LiBr, Hut-78, HCT116+, FBL-3, C6, astrocyte, 3T3-L1, NIH3T3, Vero and MDCK cell lines were all maintained in our laboratory and cultured in RPMI-1640 or DMEM supplemented with $10 \%$ fetal calf serum. The medium for cell lines expressing the neomycin resistance gene was supplemented with $0.5 \mathrm{mg} / \mathrm{ml} \mathrm{G} 418$. Human epithelial tissue, normal human peripheral blood mononuclear cells (PBMCs), M5 patient and non-M5 acute leukemia patient PBMCs were all obtained from over 30 cases of patients or healthy young individuals. Mouse splenocytes were obtained from 30 mice.

Antibodies and reagents. CAB39L and MLAA-34 share the same open reading frame (ORF), the CAB39L antibody was used in this report. Antibodies specific for CAB39L (sc-100390), $\beta$-catenin (sc-133240), Rab-3D (sc-26559), Rap-1B (sc-1481) and PGK1 (sc-130335) were purchased from Santa Cruz Biotechnology, Inc. (Santa Cruz, CA, USA). A monoclonal mouse antibody against $\beta$-actin was obtained from SigmaAldrich (St. Louis, MO, USA). The SAP kit and AP-Red kit were provided by Zhongshan Co. Beijing, China (SAP-9102, ZLI-9042). The lentivirus packaging system and enhanced infection solution (ENi.S) were purchased from GeneChem Limited Company (Shanghai, China). The SYBR Green PCR kit and SYBR Master Mixture were purchased from Takara Bio, Inc. (Dalian, China). The Endo-free Plasmid Mini kit was purchased from Qiagen, USA (12163). M-PER ${ }^{\circledR}$ Mammalian Protein Extraction Reagent was purchased from Pierce, Rockford, IL, USA (78503).

Western blot analysis. Cells were collected at a concentration of $2 \times 10^{7} / \mathrm{ml}$. Following sodium dodecyl sulfate polyacrylamide gel electrophoresis (SDS-PAGE), the proteins were transferred to polyvinylidene fluoride membranes, which were incubated with the primary antibody CAB39L (1:200). Western blot analyses were performed according to standard methods. The protein bands were visualized by applying SuperSignal West Pico Chemiluminescent Substrate (34079; Pierce). The exposed film was then analyzed using a densitometer.

Immunohistochemistry and immunofluorescence. For analysis of the subcellular localization of MLAA-34, U937 cells were washed with ice-cold PBS, blocked with $10 \%$ normal goat serum and incubated with a primary antibody against
CAB39L at a dilution of 1:50 for $2 \mathrm{~h}$ at $37^{\circ} \mathrm{C}$. Next, the cells were washed again and incubated with the appropriate biotinylated secondary antibody (goat anti-mouse IgG antibody) for $20 \mathrm{~min}$ at $37^{\circ} \mathrm{C}$. Incubation with serum alkaline phosphatase (SAP; ALP) was then performed at $37^{\circ} \mathrm{C}$ for $20 \mathrm{~min}$, and the immunolabeling was visualized with a mixture of AP-Red solution. Counterstaining with hematoxylin was performed. For immunofluorescence, the cell samples were incubated with the monoclonal antibody CAB39L (diluted 1:50) and fluorescein isothiocyanate (FITC)-labeled or rhodaminelabeled goat anti-mouse $\mathrm{IgG}$ as the primary and secondary antibodies, respectively. The mounted cells were visualized with a fluorescent microscope.

Construction and identification of the MLAA-34 lentivirus vector and upregulated MLAA-34 stably transfected cell line. The full-length MLAA-34 cDNA sequence was assembled by searching the NCBI database and amplified by RT-PCR from U937 cells. First-strand cDNA synthesis was performed using a commercial kit (Boehringer Mannheim, Milan, Italy). The restriction enzyme site for AgeI (ACCGGT) was introduced into the 5' and 3 ' PCR primers. To generate cDNA coding for fulllength MLAA-34 by PCR, the following primers were designed using plasmid MLAA-34 as the template: MLAA-34-Age, I-F, GAGGATCCCCGGGTACCGGTCGCCACCATGAAAAAA ATGCCTTTG and MLAA-34-Age, I-R, TCACCATGGTGGC GACCGGAGGGGCCGTTTTCTTCAAG. The PCR conditions consisted of 30 cycles, and the cycle parameters were: $94^{\circ} \mathrm{C}$ for $5 \mathrm{~min}$, then 30 cycles of $94^{\circ} \mathrm{C}$ for $30 \mathrm{sec}, 55^{\circ} \mathrm{C}$ for $30 \mathrm{sec}, 68^{\circ} \mathrm{C}$ for $1 \mathrm{~min}$, followed by a final extension of $68^{\circ} \mathrm{C}$ for $10 \mathrm{~min}$. The PCR product was purified using an Agarose Gel DNA Purification kit (Takara Bio, Inc.). The two recovered products were ligated using an In-Fusion kit (631774; Becton, Dickinson and Co., USA). To confirm that the ligation was correct, MLAA-34-SEQF, GACAGATAGGCACTCGGAG; Ubi-F, GGGTCAATATGTAATTTTCAGTG; and EGFP-N-R, CGTCGCCGTCCAGCTCGACCAG primers were designed. The cycle parameters were: 30 cycles of $94^{\circ} \mathrm{C}$ for $30 \mathrm{sec}, 94^{\circ} \mathrm{C}$ for $30 \mathrm{sec}, 60^{\circ} \mathrm{C}$ for $30 \mathrm{sec}, 72^{\circ} \mathrm{C}$ for $50 \mathrm{sec}$, followed by a final extension of $72^{\circ} \mathrm{C}$ for $6 \mathrm{~min}$. For detection of MLAA-34 expressed by recombinant lentivirus in vitro, purified pGCFU-MLAA-34 vectors were transfected into 293T cells using Lipofectamine 2000 reagent (11668-019; Invitrogen, Carlsbad, CA, USA) according to the manufacturer's instructions. This vector was termed MLAA-34-Lentivirus, and the vector without MLAA-34 cDNA was pGC-FU-GFP-LV. The titer of the recombinant lentivirus was determined by real-time qPCR on 293T cells. For identification of the recombinant MLAA-34 lentivirus vector, the virus was added to targeted U937 cells at multiplicity of infections (MOIs) of 10, 20, 50, 80, 100, 120 and 200 with ENi.S and $5 \mu \mathrm{g} / \mathrm{ml}$ polybrene. MLAA-34-Lentivirus and pGC-FU-GFP-LV transfected U937 cells were used as the test, and non-transfected cells were used as the control. The expression level of MLAA-34 was detected by western blot analysis and RT-PCR. The best MOI was chosen.

Cells were grown in selective media (containing G418) for two weeks, expanded and grown as independent clones for at least two weeks. Resistant colonies were counted, and the expression of GFP was confirmed by fluorescence microscopy, RT-PCR and western blot analysis. 
Fluorescence microscopy, MTT, flow cytometry and DNA ladder. To determine the effect of upregulation of MLAA-34 by the MLAA-34-Lentivirus, non-transfected cells and cells transfected with pGC-FU-GFP-LV and MLAA-34-Lentivirus were examined. Cells were seeded in 96-well plates at a density of $1 \times 10^{4}$ cells/well. Cellular proliferation was measured once per day during a seven-day period. In brief, $20 \mu \mathrm{l}$ of sterile MTT (Sigma) dye $(5 \mathrm{mg} / \mathrm{ml})$ was added to the cells, which were then incubated for another $4 \mathrm{~h}$ at $37^{\circ} \mathrm{C}$. Then, $150 \mu \mathrm{l}$ of dimethylsulfoxide was added to each well. The spectrophotometric absorbance was measured at a wavelength of $490 \mathrm{~nm}$ on an enzyme immunoassay analyzer.

Fixed cells were stained with $2.5 \mathrm{~g} / \mathrm{ml}$ of DAPI (4',6-diamidino-2-phenylindole) solution to detect apoptotic nuclei. Quantification of apoptosis was determined by counting the number of apoptotic cells. The cells were stained using an Annexin V-PE/7-AAD apoptosis detection kit (KGA1015; Nanjing KeyGen Biotech. Co., Ltd.) according to the manufacturer's instructions and were analyzed by flow cytometry using a Beckman Coulter flow cytometer.

For cell cycle analysis, the cells were fixed in $70 \%$ ethanol and stained with propidium iodide (PI; Biosea Biotechnology Co., Beijing, China) at a final concentration of $20 \mu \mathrm{g} / \mathrm{ml}$ in Triton X-100 containing $10 \mathrm{mg} / \mathrm{ml}$ RNase. Following incubation, the samples were analyzed on a flow cytometer.

Fragmented DNA was isolated using a DNA extraction kit (C0008; Beyotime) according to the manufacturer's instructions. The eluants containing DNA pellets were electrophoresed on a $1 \%$ agarose gel at $80 \mathrm{~V}$ for $1.5 \mathrm{~h}$. The gel was examined and photographed using an ultraviolet gel documentation system.

Co-immunoprecipitation (Co-IP) and SDS-PAGE. Co-IP was performed using a Profound ${ }^{\mathrm{TM}}$ Mammalian Co-IP kit (23605; Pierce). Transfected U937 cells $\left(2 \times 10^{7} / \mathrm{ml}\right)$ were washed, centrifuged and resuspended in lysis buffer for incubation. The cell lysates were centrifuged to remove the supernatant material, and the CAB39L antibody was cross-linked to the antibody coupling resin. The lysed cell sample was then applied to the antibody support to form immune complexes. Then, unbound proteins were washed away three times. The samples were then eluted, and coupling buffer was added to obtain the immunoprecipitated protein. Finally, the Co-IP protein concentrations were determined using a BCA Protein Assay kit (23225; Pierce). The proteins were analyzed by SDS-PAGE, and the gel was stained with Coomassie Blue.

Mass spectrometry analysis (MS, shotgun) and protein identification. After separation by SDS-PAGE, discrete bands were excised from and subjected to in-gel tryptic digestion. The extracted peptides were analyzed using shotgun HPLCESI-MS proteomics approach (LTQ; Thermo Finnigan, San Jose, CA, USA). High-performance liquid chromatography (HPLC) separation was performed with a capillary LC pump. The mobile phases used for the reverse phase were i) $0.1 \%$ formic acid in water, $\mathrm{pH} 3.0$; ii) $0.1 \%$ formic acid in $\mathrm{ACN}$. The collision energy was set automatically by the LTQ system. Following acquisition of full scan mass spectrum, three MS/MS scans were acquired for the next three most intense ions using dynamic exclusion. Peptides and proteins were identified using

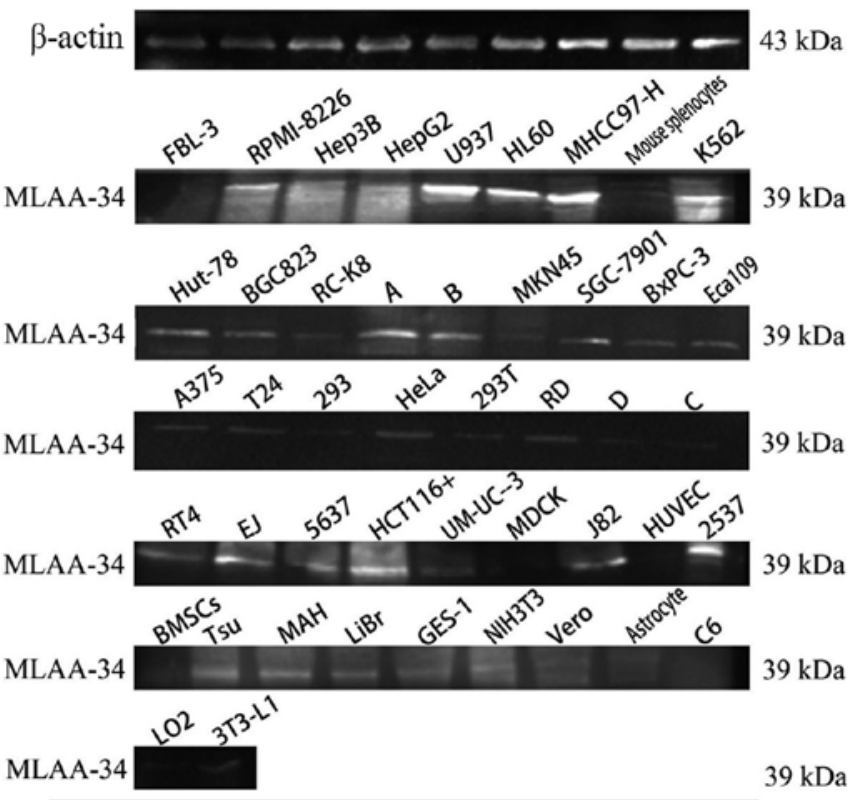

Figure 1. Expression of MLAA-34 by western blot analysis. A, commixture of M5 patient PBMCs; B, commixture of non-M5 acute leukemia patient PBMCs; C, normal human PBMCs; D, human epithelial tissue.

Bioworks Browser 3.1 software (Thermo Finnigan), which uses the MS and MS/MS spectra of peptide ions to search against the NCBI human protein database. The protein identification criteria that we used were based on Delta $\mathrm{CN}(\geq 0.1)$ and Xcorr (one charge $\geq 1.9$, two charges $\geq 2.2$, three charges $\geq 3.75$ ). The protein identification results were extracted from the SEQUEST out file with in-house software (BuildSummary). The cellular localization, molecular function and biologic process were determined using the gene ontology annotation DAVID (http:// david.abcc.ncifcrf.gov/). For pathway analysis, the KEGG database was searched. To identify the corresponding proteins in mixed protein obtained by Co-IP, western blot analysis was performed as previously described.

Statistical analysis. The RT-PCR results were analyzed by the self-contained software of iQ5 (Bio-Rad Co.). Statistical analyses were performed using an analysis of variance (ANOVA). All results are expressed as the means \pm standard deviations from at least three experiments. $\mathrm{P}<0.05$ was considered to indicate statistically significant differences.

\section{Results}

Expression of human MLAA-34 protein. With western blot analysis, a strong specific band of $\sim 39 \mathrm{kDa}$ was observed in U937 and MHCC97-H cells, and reduced expression was observed in other leukemia or lymphoma cell lines and PBMCs from leukemia patients. Much fainter bands were observed in solid tumor cell lines, and no expression was detected in normal human cell lines or primary animal cells (Fig. 1).

Identification and cellular localization of MLAA-34. Immunohistochemical staining confirmed the presence of MLAA-34 in U937 cells and the subcellular localization was detected primarily in the cytomembrane and cytoplasm (Fig. 2). 

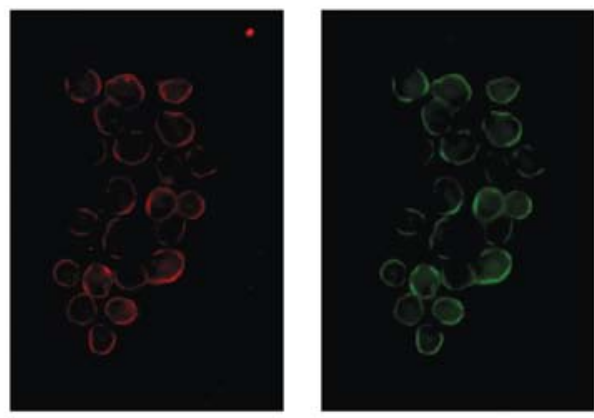

MLAA-34

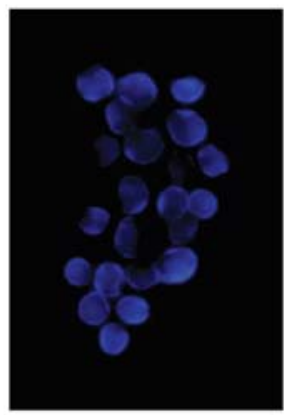

DAPI

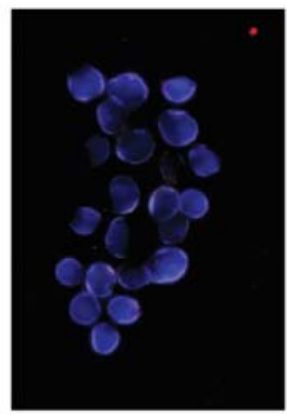

Merge

Figure 2. The subcellular localization of MLAA-34 protein in U937 cells (x40). The MLAA-34 protein was distributed predominantly in the cytomembrane and cytoplasm (red or green). The nuclei were stained by DAPI (x40).

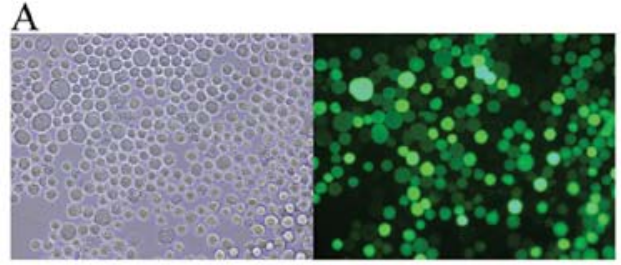

$\mathrm{MOI}=20$

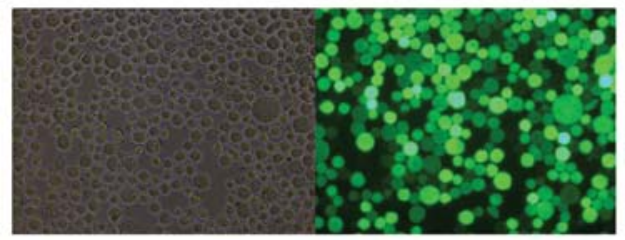

$\mathrm{MOI}=50$

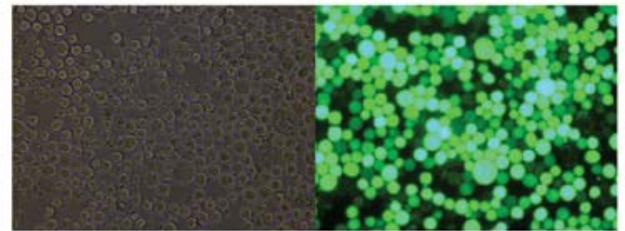

$\mathrm{MOI}=80$

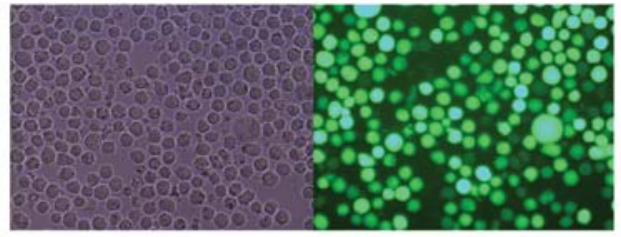

pGC

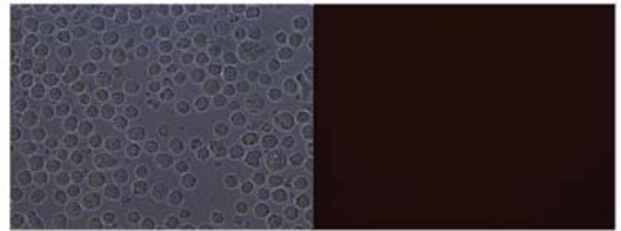

Non-transfected U937
B

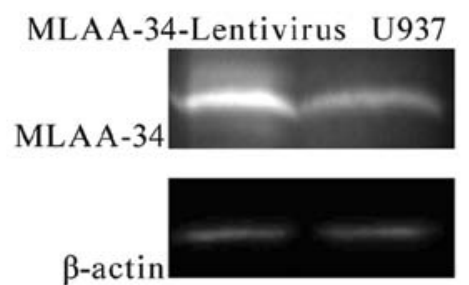

MLAA-34-Lentivirus U937

MLAA-34

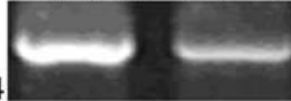

$\beta$-actin

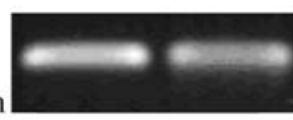

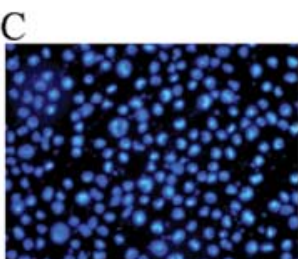

Transfected with MLAA-34-Lentivirus

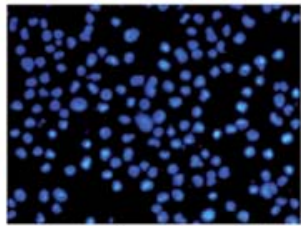

Transfected with pGC FU-GFP-LV

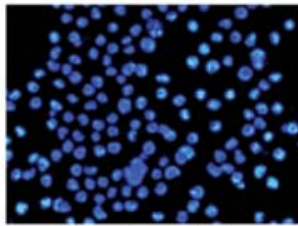

Non-transfected
D

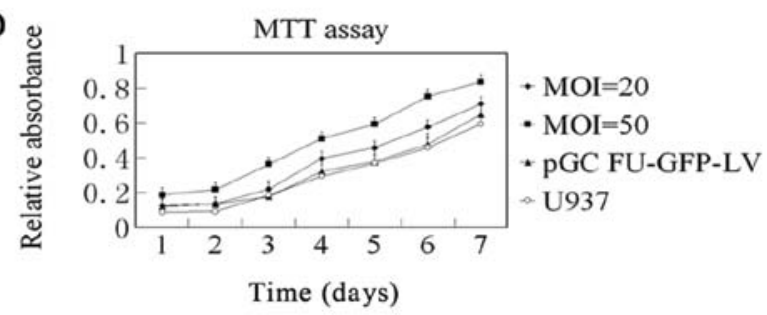

E
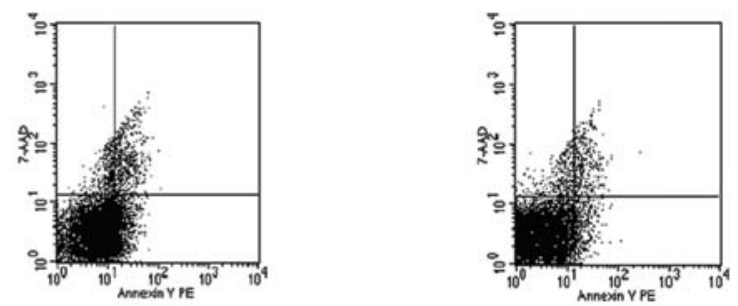

U937 cells (LR:13.16, UR:6.76) MOI=50 (LR:3.53, UR:3.14)

Figure 3. Lentivirus-mediated gene transfer system for overexpression of MLAA-34 was constructed successfully and markedly decreases apoptosis and promotes proliferation in U937 cells. (A) Morphological observation of MLAA-34-Lentivirus transfected U937 cells at different MOIs. The transfection efficiency was higher at MOI=50 and 80, but the growth condition was the best at MOI=50. (B) MLAA-34-Lentivirus upregulated the expression of MLAA-34 in U937 cells, estimated by western blot analysis (left) and RT-PCR (right). (C) Morphological changes in the morphology of the cell nucleus were observed by DAPI staining (blue). (D) Cell viability was measured by MTT assays. (E) The cells were stained with Annexin V-PE and 7-AAD for flow cytometry analysis.

MLAA-34 is upregulated by the lentiviral vector. A human MLAA-34 lentivirus gene transfer vector encoding the green fluorescent protein (GFP) sequence was constructed. The pGC-
FU-MLAA-34-GFP plasmid has an insert of $771 \mathrm{bp}$, which is in accord with the MLAA-34 cDNA [identities, 1009/1012 (99\%)]. The pilot experiments showed that $293 \mathrm{~T}$ cells could 
A

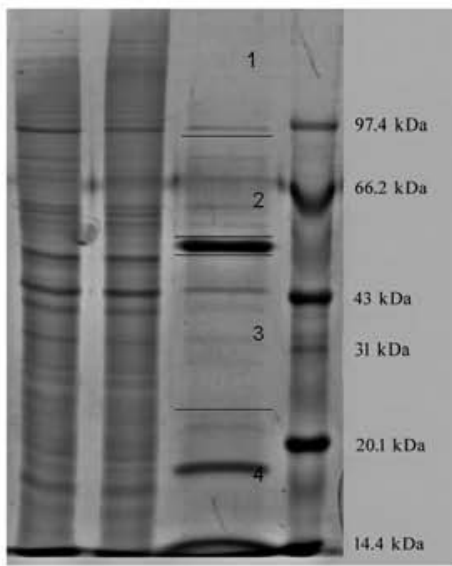

C

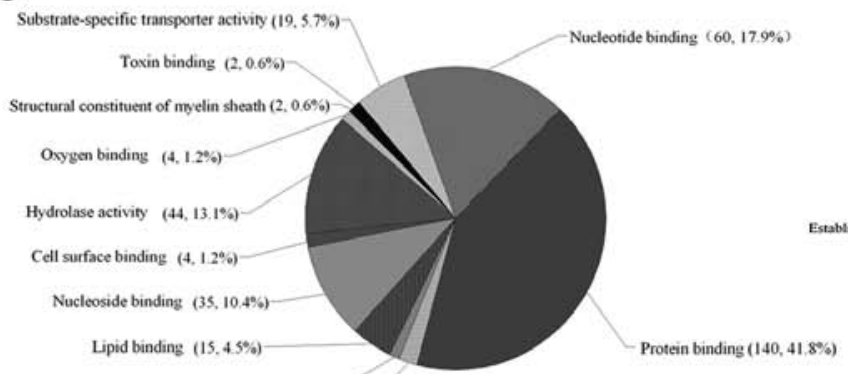

Nitric-oxide synthase regulator activity $(3,0.9 \%)$

Structural constituent of cytoskeleton $(7,2.1 \%)$

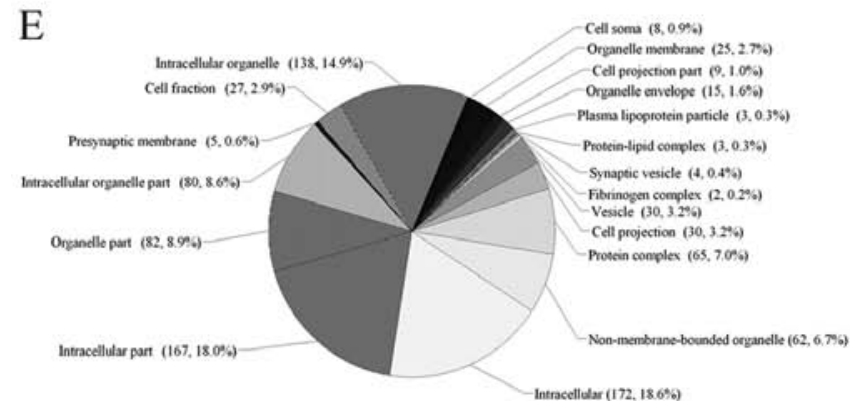

F

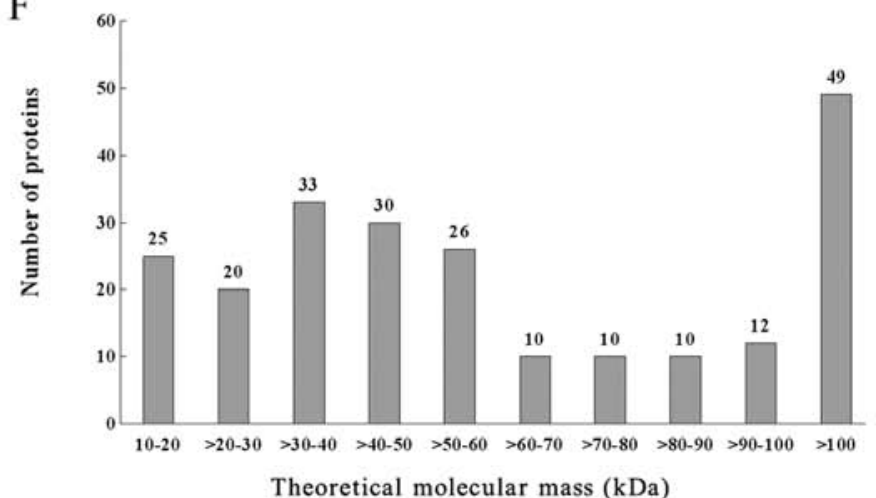

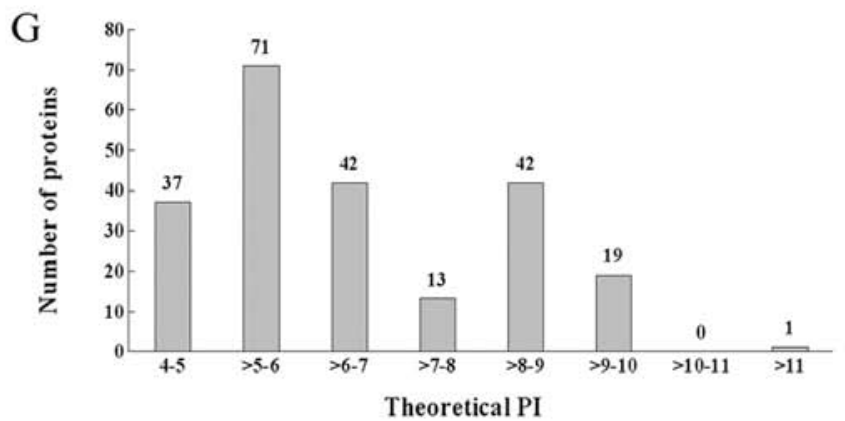

Figure 4. Proteomics analysis of MLAA-34 in stably transfected U937 cells. (A) SDS-PAGE gel images after Co-IP and the cutting sites in the gel band. Four spaced sections were excised. From left to right were cell lysate, elutriant after Co-IP, sediment after Co-IP and marker. (B) Western blot analysis. The major bands that migrated at $21,25,92$ and $45 \mathrm{kDa}$ corresponding to Rap-1B, Rab-3D, $\beta$-catenin and PGK1. (C-E) Numbers and percentages of the annotated proteins with molecular function, biological process and cellular localization. (F and $\mathrm{G})$ Distributions of theoretical molecular mass and PI for all of the annotated proteins.

be successfully infected by the packaged virus; the virus titer reached higher than $2 \times 10^{8} \mathrm{TU} / \mathrm{ml}$, indicating that a high-titer lentiviral packaging platform was preliminarily established. The pGC-FU-MLAA-34-GFP plasmid was confirmed by western blot analysis. MLAA-34-Lentivirus and control pGCFU-GFP-LV virus were produced. After obtaining ideal U937 cells, we transfected the cells with the MLAA-34-Lentivirus and pGC-FU-GFP-LV viruses at different MOIs. The transfec- 


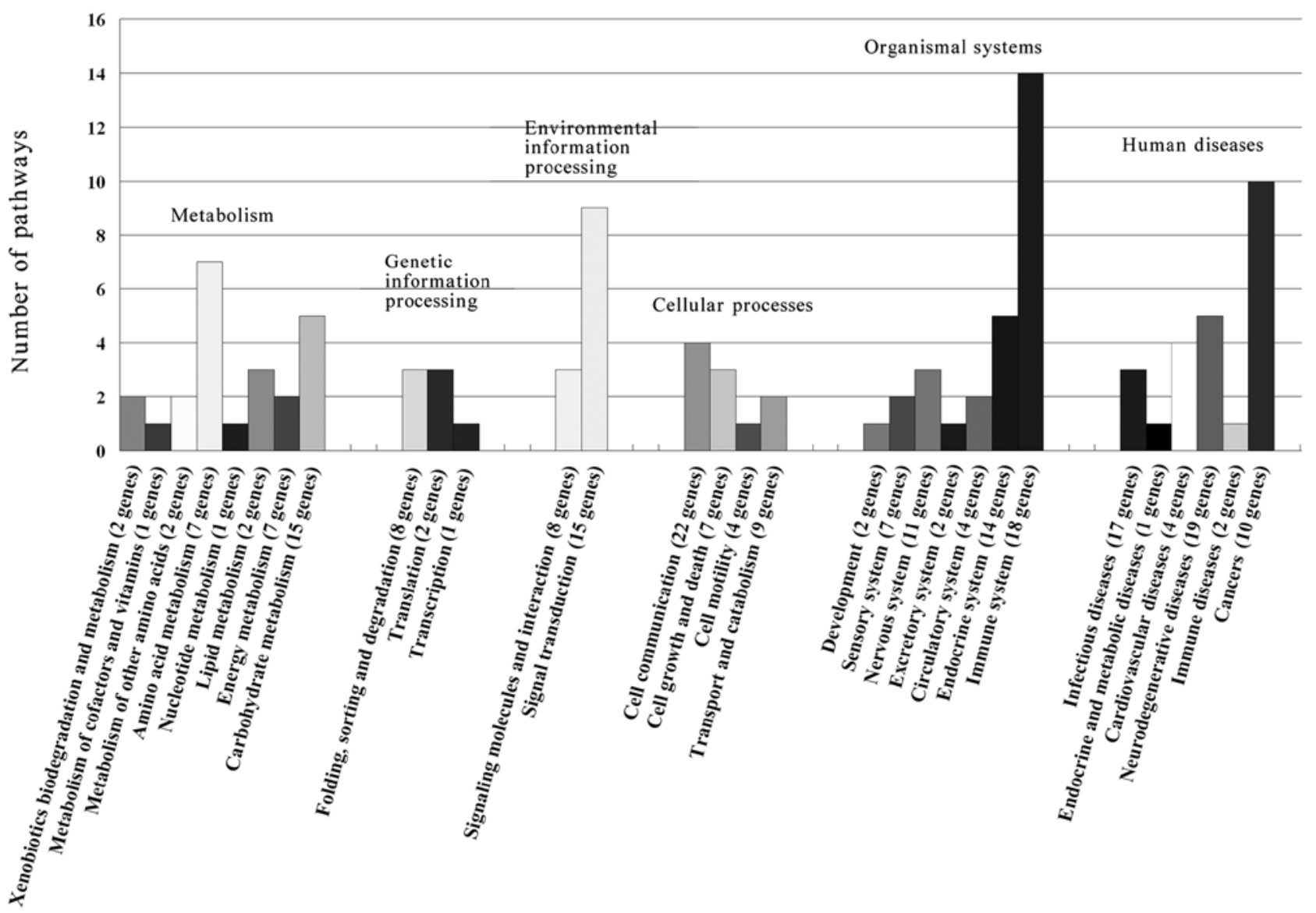

Figure 5. Categories of related pathways in 225 annotated proteins according to KEGG pathway taxonomy.

tion efficiency was $\sim 95 \%$ or higher on Day 5 or later at the MOI of 50 (Fig. 3A). Five days after transfection, the recombinant MLAA-34-Lentivirus caused a pronounced increase in the expression of MLAA-34 compared with non-transfected U937 cells (Fig. 3B).

Establishment of U937 cell line stably overexpressing MLAA-34. In preliminary studies, $400 \mu \mathrm{g} / \mathrm{ml}$ of G418 were found to maintain adequate selection pressure. The expression of GFP and MLAA-34 were observed. After the cells had been frozen in liquid nitrogen for six months and revived monthly, the U937 cells expressed higher levels of MLAA-34 in $\sim 400 \mu \mathrm{g} / \mathrm{ml}$ of G418, and $~ 95 \%$ of the lentivirus-transfected U937 cells overexpressed MLAA-34. These results suggested that the stably transfected U937 cell line was successfully established by lentivirus and that the expression of MLAA-34 can be long lasting even after passage.

Effect of upregulating MLAA-34 on apoptosis and growth of U937 cells. Observations of morphology revealed increasing cell shrinkage, nuclear condensation and fragmentation in nontransfected and pGC-FU-GFP-LV transfected cells. By contrast, cells transfected with MLAA-34-Lentivirus predominantly appeared uniformly stained without condensation (Fig. 3C). These results further support the findings that anti-apoptotic changes in the cell and nuclear morphology are induced by MLAA-34 overexpression. MTT assays suggested that the lentiviral overexpression of MLAA-34 induces anti-apoptotic effects that result in a promotion effect on U937 cells; these data suggest that MLAA-34 might accelerate cell proliferation (Fig. 3D). In agreement with the anti-apoptotic effects of MLAA-34, cells overexpressing MLAA-34 accumulated in the S-phase ( $67.63 \%$ compared with $\sim 49.6 \%$ of cells in the S-phase in the control) and showed a corresponding increase in cell numbers in the G2/M phase. The percentages of early (lower right) and late apoptotic (upper right) cells were markedly reduced in U937 cells after transfection with MLAA-34-Lentivirus (Fig. 3E). These results are in agreement with the DNA ladder assay and are even more evident at the $\mathrm{MOI}=50$, in which the cells transfected with MLAA-34-Lentivirus showed a further increase. All of these results suggest that MLAA-34 inhibits apoptosis in U937 cells.

Co-IP, shotgun and western blot analysis. Protein extracts with Co-IP were separated by SDS-PAGE and the gel was cut into four pieces for shotgun ESI-MS analysis (Fig. 4A). A total of 256 proteins were identified by the LC ESI-MS analysis and BIOWORKS in the NCBI HUMAN protein databases, of which $225(87.9 \%)$ proteins were annotated by DAVID and the remaining 31 (12.1\%) proteins have no DAVID terms (Table I). The expression of Rap-1B, Rab-3D, $\beta$-catenin and PGK1 was verified by western blot analysis (Fig. 4B).

Classification of the 225 annotated proteins in terms of molecular function, biological process and cellular localization was performed according to the DAVID. Molecular function was clustered and the protein binding $(140,41.8 \%)$ and nucleotide binding $(60,17.9 \%)$ groups were the majority (Fig. 4C). 

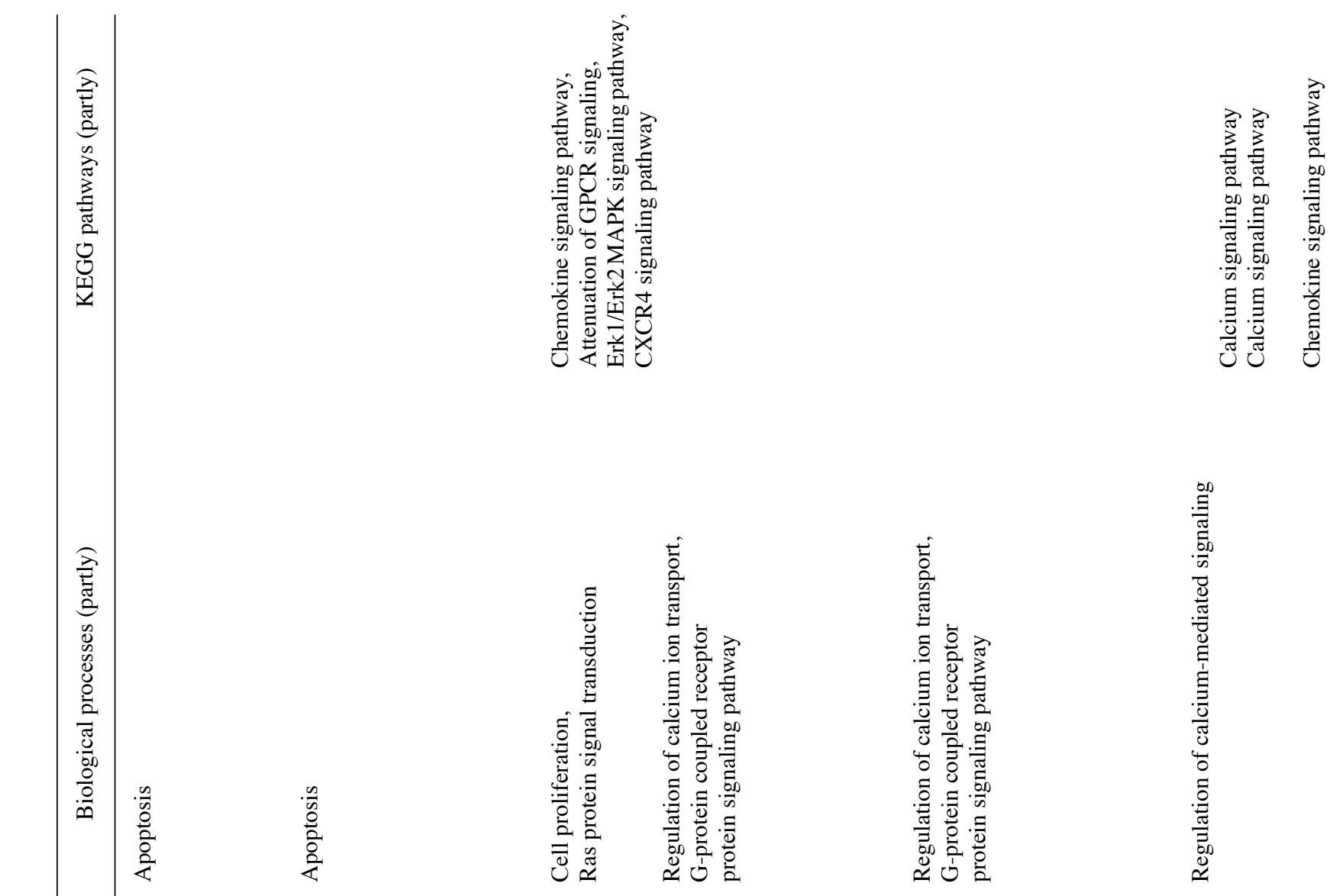

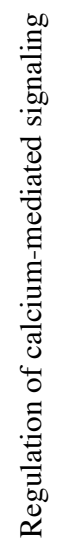
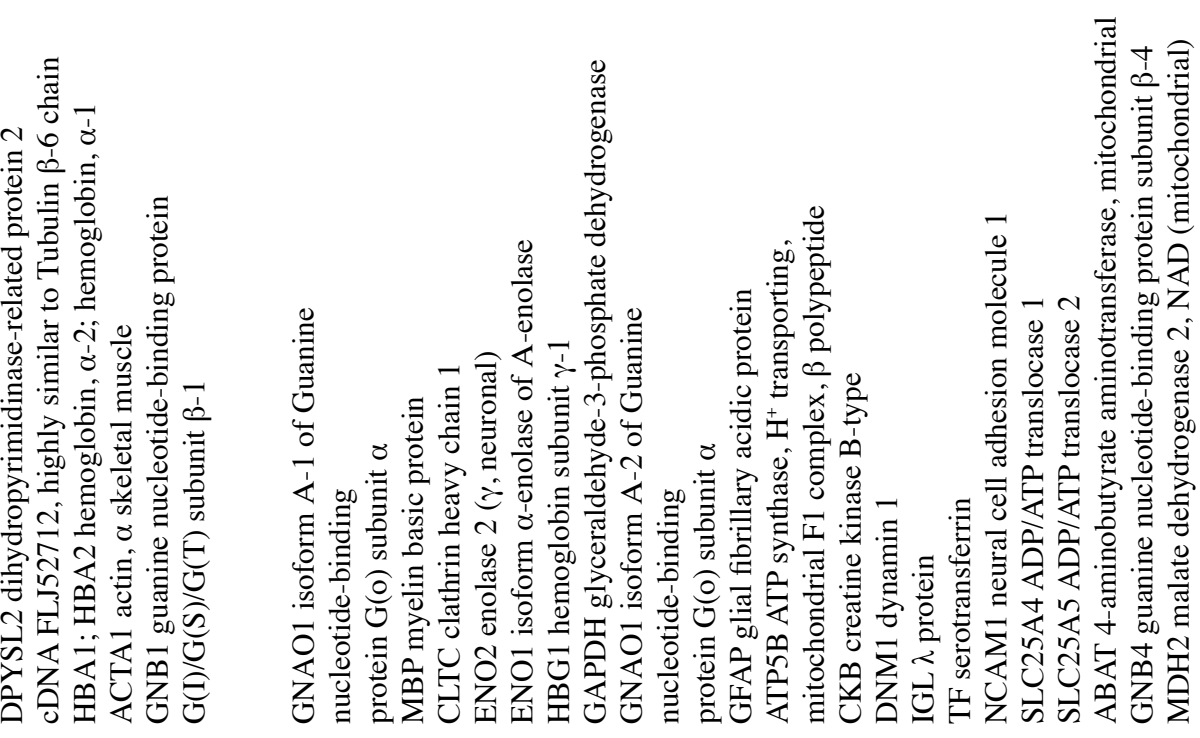

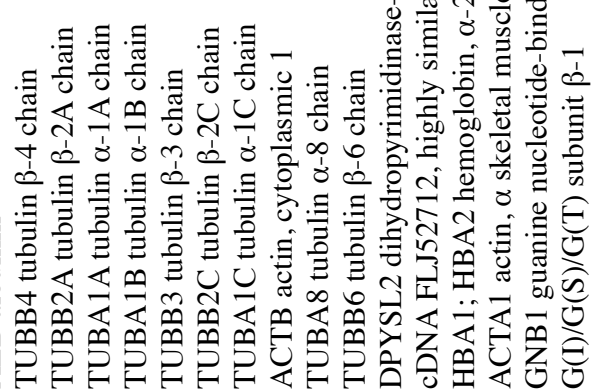

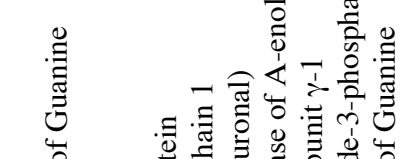

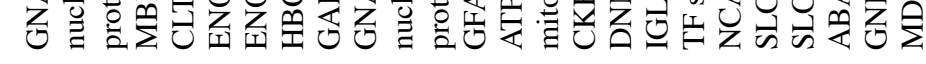
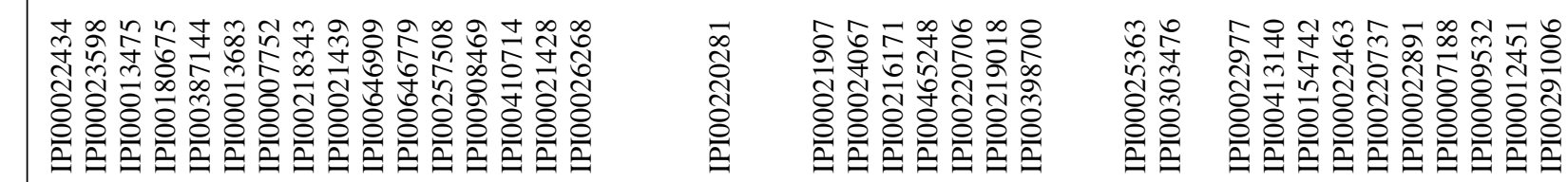







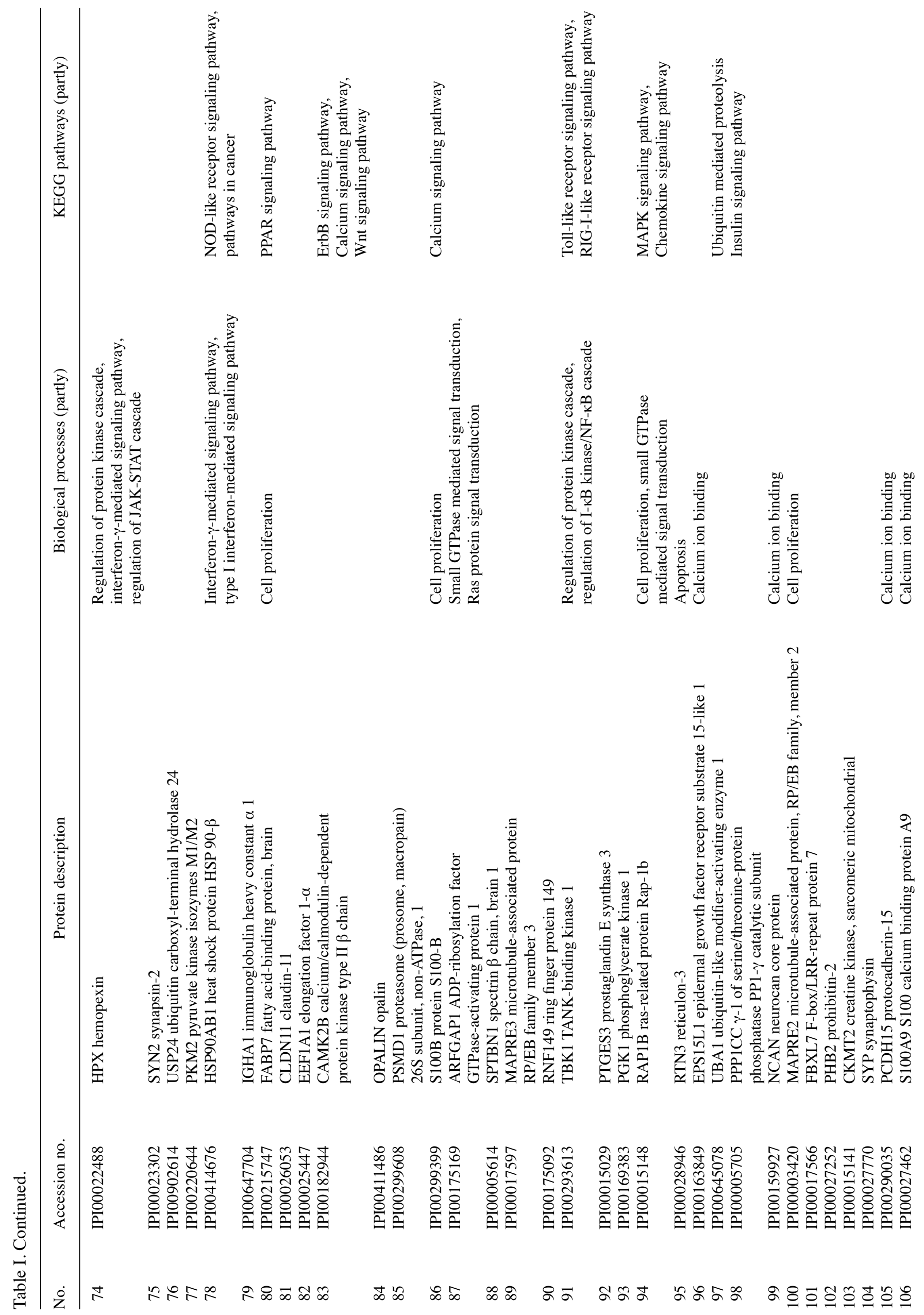




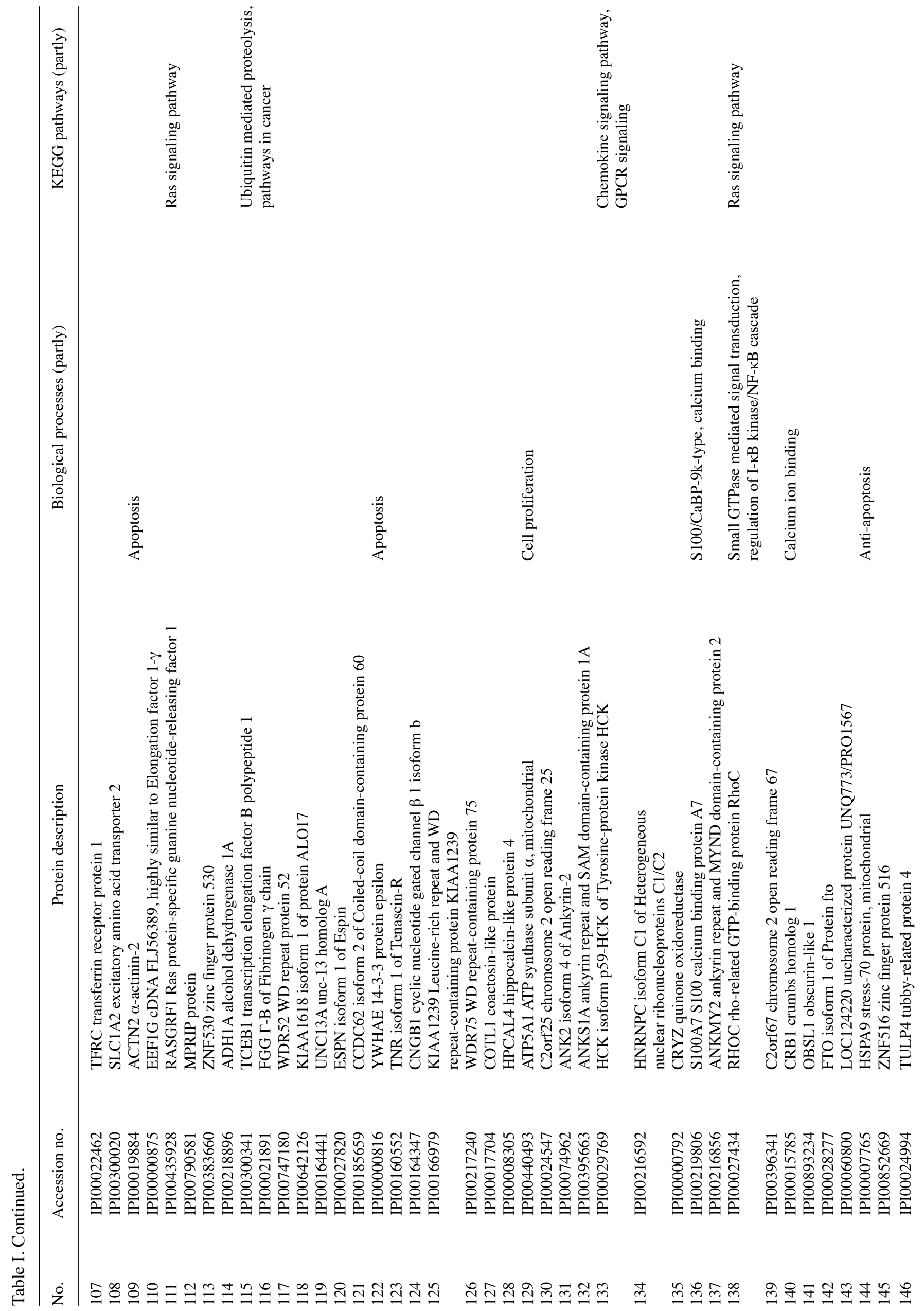



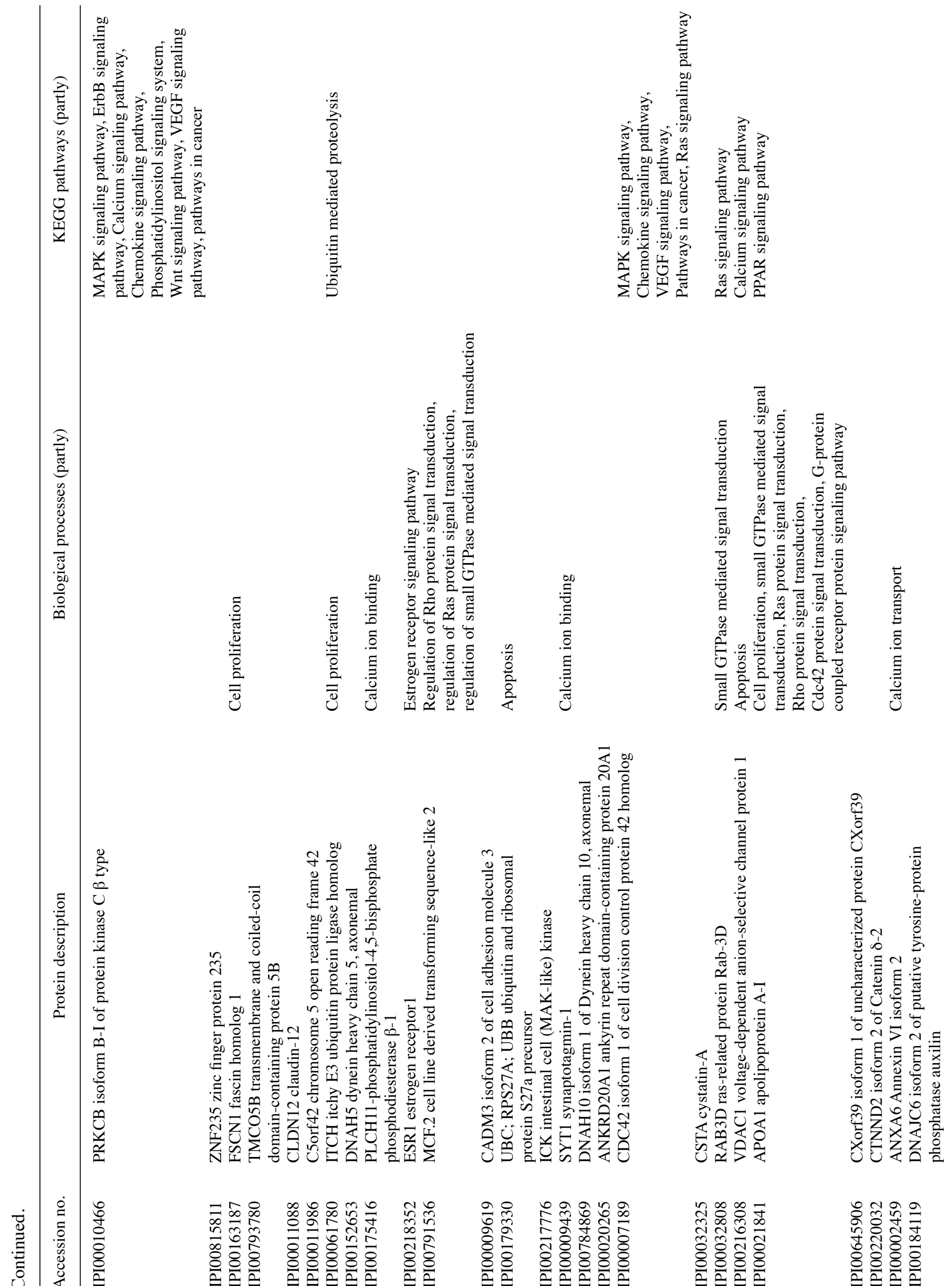

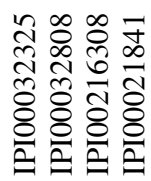

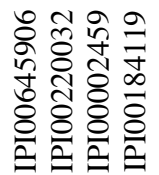

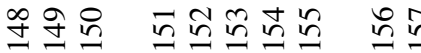

象

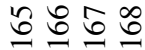

응으토도 


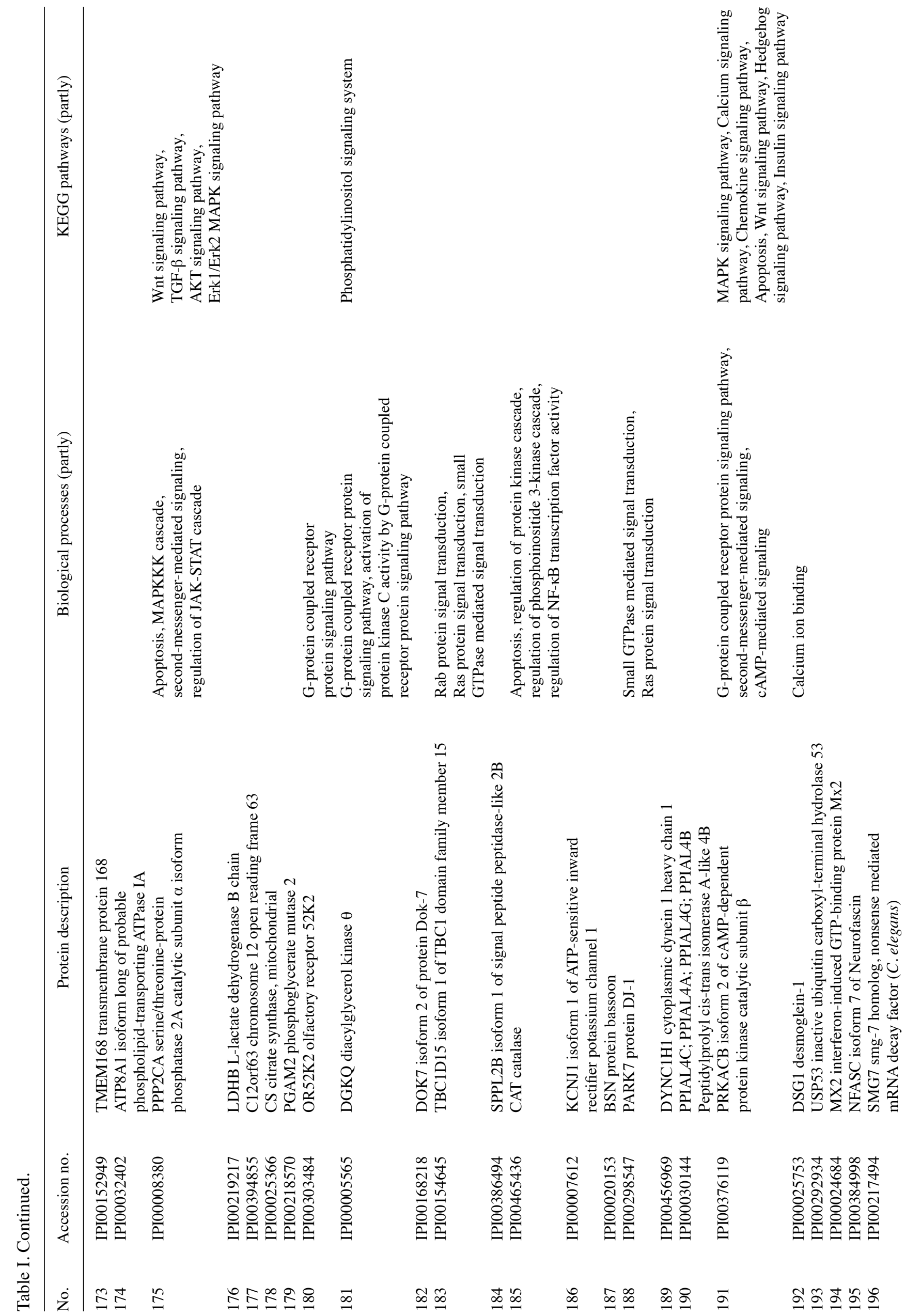




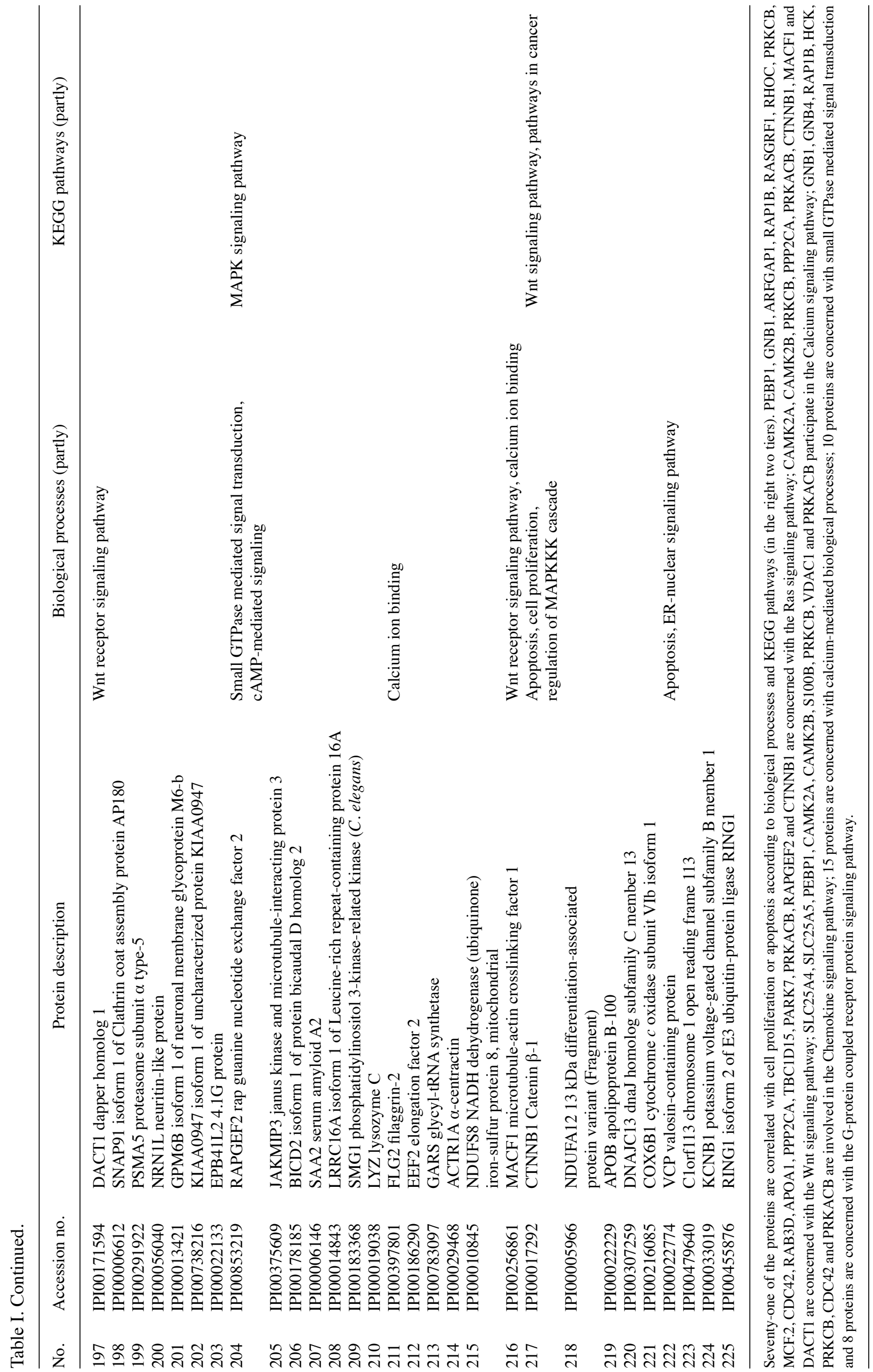


For biological processes, annotated proteins are particularly involved in the cell process $(167,27.5 \%)$ and the multicellular organismal process $(75,12.4 \%)$ (Fig. 4D). Most $(172,18.6 \%)$ of the annotated proteins were localized in the intracellular (Fig. 4E). Distribution of molecular mass and isoelectric points (PI) of the annotated proteins was analyzed. Molecular mass ranged between 10.19 and $620.42 \mathrm{kDa}$ in size, most of them were between 10 and $60 \mathrm{kDa}$ (Fig. 4F). PI of the proteins ranged between 4.35 and 11.05 with the most PIs between four and ten (Fig. 4G). To uncover the signaling pathways of the 225 annotated proteins, the protein sequences were searched against the KEGG reference pathway database. The pathways were ascribed to metabolism, genetic information processing, environmental information processing, cellular processes, organismal systems and human diseases (Fig. 5). Among them, the immune system, cancer and signal transduction were more than others. On the other hand, the specific expressed proteins related pathways displayed more differences and 71 proteins were involved in cell apoptosis or proliferation biological processes and KEGG pathways (Table I).

\section{Discussion}

In this study, to evaluate the function of MLAA-34 in M5 cells, we used the well-characterized cell line U937. In our previous research, we reported that the MLAA-34 protein is probably a cytoplasmic protein predicted by the amino acid sequence analysis of the encoded protein (7). Here, we verified that MLAA-34 is localized in the cytoplasm and cell membrane. Western blot analysis showed that the expression of MLAA-34 differed between different cell types and was observed to be stronger in U937. Although U937 cells are generally difficult to transfect, the U937 cells were transfected with MLAA-34Lentivirus and pGC-FU-GFP-LV. A stably transfected U937 cell line was successfully established and expressed MLAA-34 at a high level, which aided in the study exploring the effect of MLAA-34 on M5 and will be critical for further research using U937 cells and animal models. In addition, an analysis of the cell morphology, apoptosis, proliferation and cell cycle revealed that the overexpression of MLAA-34 markedly inhibited apoptosis of U937 cells. These results suggested that MLAA-34 maybe a novel anti-apoptotic factor of M5, which is consistent with the RNAi in our previous study.

The proteins that interact with MLAA-34 or CAB39L remain unclear. To analyze complex mixtures of proteins, shotgun is considered the most powerful $(9,10)$. Using the MLAA-34 protein as bait, 256 proteins were identified and 225 of them have DAVID terms. Among these proteins, 71 proteins correlated with cell apoptosis or proliferation biological processes and KEGG pathways. Twenty-eight proteins are involved in cell apoptosis or proliferation; nine proteins are associated with the calcium signaling pathway and seven proteins participate in the chemokine signaling pathway; 17 proteins are concerned with the Ras signaling transduction pathway and 8 proteins are concerned with Wnt signaling pathway. The Ras, Wnt, calcium and chemokine signaling pathways may be involved in anti-apoptosis with MLAA-34 in U937 cells. As is known, the Ras family plays an important role in the molecular pathogenesis of myeloid leukemia, and Ras mutations have been preferentially associated with monocytic subtypes in AML (11). The Ras and Wnt signaling pathways are known to be key anti-apoptosis pathways in AML-M5 (12). Understanding the molecular genetics of leukemia has led to an appreciation that particular molecular abnormalities give rise to specific subtypes of the disease. For example, in myeloid leukemogenesis, PML-RAR- $\alpha$ and BCR-ABL are defining features of acute promyelocytic leukemia and chronic myeloid leukemia, respectively (13). In this case, MLAA-34 may either play an important role in leukemogenesis or play a dual role in subsequent differentiation, as in the case of PML/RAR. The results suggest that MLAA-34 might be an important agent for subtype diagnosis in AML. However, an understanding of how these identified proteins or pathways interact with MLAA-34 requires further study.

In addition to the typical pathways such as pathways in cancer and apoptosis, there were several notable pathways such as the GPCR signaling, the insulin signaling pathway, the ErbB signaling pathway, the NOD-like receptor signaling pathway, the Ahr signal transduction pathway, the AKT signaling pathway, the Toll-like receptor signaling pathway, the RIG-I-like receptor signaling pathway, the ubiquitin mediated proteolysis, the hedgehog signaling pathway, the phosphatidylinositol signaling system, the PPAR signaling pathway, the VEGF signaling pathway and the TGF- $\beta$ signaling pathway worthy of further validation (Table I). Otherwise, there are some proteins mainly involved in tumorigenesis concerned with MLAA-34 as discussed below. PGK1 is secreted by tumor cells and may play a role in inhibiting tumor angiogenesis (14). GAPDH has been shown to be upregulated in several types of cancer and downregulated by chemotherapeutic drugs, and could be considered a potential target to observe the effects of bisphosphonates on cancer cells (15). In addition, GAPDH was the best control gene in the apoptosis pattern on the myeloid cell lines (16). CRMP1 is a suppressor of tumor cell invasion of the local stroma and might be a functional modulator of the Wnt signaling pathway in vivo $(17,18)$. As the trigger of TBK-1 pathway, TBK1 is important for tumor angiogenesis and tumor-associated microvascular inflammation and expressed at significant levels in many solid tumors $(19,20)$. A recent study has demonstrated that SEPT7 could function in gliomagenesis and in the suppression of glioma cell proliferation (21).

Markedly, some 553 or caspase-related proteins were also identified, such as CLTC, PPP2CA, SOD2, PARK7, HSPA9, TXN, ESR1 and YWHAE. CLTC associates with p53 not only in nuclei but also in cytosol, and co-localizes with p53 at the plasma membrane in human cancer cells (22). CLTC expression enhances p53-dependent transactivation (23). As a downstream mediator of the antiproliferative effects of PPP2CA, p53 plays an important role in PPP2CA-directed cell cycle arrest and apoptosis (24). The SOD2 growth-retarding functions are at least partially due to triggering of a p53-dependent cellular senescence program (25). DJ-1 (PARK7) bound to $\mathrm{p} 53$ in vitro and in vivo and they were found colocalized. DJ-1 positively regulates p53 through Topors-mediated sumoylation (26). Previous studies indicated that HSPA9 could bind to p53 and sequesters it in the cytoplasm, thus providing a mechanism of inactivation of wild-type p53 and contributing to human carcinogenesis $(27,28)$. Additional studies have shown that TXN induces p53 DNA binding activity in vitro and enhances p53-dependent expression of its target gene p21 and DNA repair 
genes (29). Additional studies also indicated that caspases could be activated by TXN due to its disulfide reducing properties (30). ESR1 might activate caspases-8, -9 and -3 and induce tumor cell apoptosis, it also showed the downregulation of $\beta$-catenin signaling implicating the suppression of proliferation and metastasis of tumor cells $(31,32)$. The cleavage of YWHAE by caspase-3 during apoptosis might contribute to cell death by preventing the association of YWHAE with Bad (33). The key event during apoptosis that is common to all pathways is the activation of caspases. P53 is a well-known tumor suppressor gene, and mutational inactivation of p53 function or deletion of the gene increases susceptibility to cancer (34-37). On the basis of these findings, we will further study the interaction between MLAA-34 and caspases or p53 to investigate the anti-apoptotic mechanisms of MLAA-34 in U937 cells.

To our knowledge, this is the first report showing the cellular localization and expression of MLAA-34 in U937 cells. We have demonstrated for the first time that the overexpression of MLAA-34 by lentivirus can significantly suppress the apoptosis of U937 cells, and a cell line stably overexpressing MLAA-34 was successfully established. Another key finding of this study is the information from proteomics evidence that MLAA-34 may be a tumor-correlated gene, and this is the first time it is revealed that the preliminary framework of proteins and pathways interlink with MLAA-34 in U937. Furthermore, it will be essential to integrate data from many different sources to obtain an accurate understanding of MLAA-34 protein networks.

Gene therapy remains the most promising, if not the only, approach to treating genetic diseases. An example of this is the use of rituximab for the treatment of lymphoma and other types of cancer. Rituximab is a mouse/human chimeric IgG(1)- $\kappa$ monoclonal antibody that targets the CD20 antigen found on the surface of malignant and normal B lymphocytes (38). Most cellular processes are performed by multiprotein complexes. The identification and analysis of their components provides insight into how the ensemble of expressed proteins (the proteome) is organized into functional units (39). Nevertheless, for a viable clinical approach, extensive research is needed in the future to regulate the expression of the target gene and improve its safety.

In conclusion, our current results provide new evidence that MLAA-34 may be a novel anti-apoptotic factor in vitro, and the data presented here show a strong correlation between anti-apoptosis with the upregulation of MLAA-34. In addition, preliminary proteomic analysis suggests that a number of genes belonging to different signaling pathways may be involved in apoptosis in U937 cells in association with MLAA-34, which would disclose a novel cross-link between MLAA-34 and the Ras, Wnt, calcium and chemokine signaling pathways. Findings of the present study will lead to a better understanding of the mechanisms involved in M5, and MLAA-34 may serve as a potential novel marker for the early diagnosis and gene therapy of M5.

\section{Acknowledgements}

This study was supported by the National Natural Science Foundation of China under award nos. 30971284, 81000219 and 18110021.

\section{References}

1. Ossenkoppele GJ, Graveland WJ, Sonneveld P, Daenen SM Biesma DH, Verdonck LF, Schaafsma MR, Westveer PH, Peters GJ, Noordhuis P, Muus P, Selleslag D, van der Holt B, Delforge M, Lowenberg B and Verhoef GE: The value of fludarabine in addition to ARA-C and G-CSF in the treatment of patients with high-risk myelodysplastic syndromes and AML in elderly patients. Blood 103: 2908-2913, 2004

2. Faderl S, Gandhi V, O'Brien S, Bonate P, Cortes J, Estey E, Beran M, Wierda W, Garcia-Manero G, Ferrajoli A, Estrov Z, Giles FJ, Du M, Kwari M, Keating M, Plunkett W and Kantarjian H: Results of a phase 1-2 study of clofarabine in combination with cytarabine (ara-C) in relapsed and refractory acute leukemias. Blood 105: 940-947, 2005.

3. Fiedler W, Serve H, Döhner H, Schwittay M, Ottmann OG, O'Farrell AM, Bello CL, Allred R, Manning WC, Cherrington JM, Louie SG, Hong W, Brega NM, Massimini G, Scigalla P, Berdel WE and Hossfeld DK: A phase 1 study of SU11248 in the treatment of patients with refractory or resistant acute myeloid leukemia (AML) or not amenable to conventional therapy for the disease. Blood 105: 986-993, 2005

4. Niitsu N, Yamamoto-Yamaguchi Y, Kasukabe T, Okabe-Kado J, Umeda M and Honma Y: Antileukemic efficacy of 2-deoxycoformycin in monocytic leukemia cells. Blood 96: 1512-1516, 2000.

5. Tallman MS, Kim HT, Paietta E, Bennett JM, Dewald G, Cassileth PA, Wiernik PH and Rowe JM: Acute monocytic leukemia (French-American-British classification M5) does not have a worse prognosis than other subtypes of acute myeloid leukemia: a report from the Eastern Cooperative Oncology Group. J Clin Oncol 22: 1276-1286, 2004.

6. Chen G, Zhang W, Cao X, Li F, Liu X and Yao L: Serological identification of immunogenic antigens in acute monocytic leukemia. Leuk Res 29: 503-509, 2005.

7. Zhang PY,Zhang WG, He AL, Wang JL and Li WB: Identification and functional characterization of the novel acute monocytic leukemia associated antigen MLAA-34. Cancer Immunol Immunother 58: 281-290, 2009.

8. Zhao J, He A, Zhang W, Meng X and Gu L: Quantitative assessment of MLAA-34 expression in diagnosis and prognosis of acute monocytic leukemia. Cancer Immunol Immunother 60: 587-597, 2011.

9. Lu B, McClatchy DB, Kim JY and Yates JR III: Strategies for shotgun identification of integral membrane proteins by tandem mass spectrometry. Proteomics 8: 3947-3955, 2008.

10. He P, He HZ, Dai J, Wang Y, Sheng QH, Zhou LP, Zhang ZS, Sun YL, Liu F, Wang K, Zhang JS, Wang HX, Song ZM, Zhang HR, Zeng R and Zhao X: The human plasma proteome: analysis of Chinese serum using shotgun strategy. Proteomics 5: 3442-3453, 2005.

11. Bowen DT, Frew ME, Hills R, Gale RE, Wheatley K, Groves MJ, Langabeer SE, Kottaridis PD, Moorman AV, Burnett AK and Linch DC: RAS mutation in acute myeloid leukemia is associated with distinct cytogenetic subgroups but does not influence outcome in patients younger than 60 years. Blood 106: 2113-2119, 2005.

12. Morgan MA, Dolp O and Reuter CW: Cell-cycle-dependent activation of mitogen-activated protein kinase kinase (MEK-1/2) in myeloid leukemia cell lines and induction of growth inhibition and apoptosis by inhibitors of RAS signaling. Blood 97: 1823-1834, 2001.

13. Pearn L, Fisher J, Burnett AK and Darley RL: The role of PKC and PDK1 in monocyte lineage specification by Ras. Blood 109: 4461-4469, 2007.

14. Lay AJ, Jiang XM, Kisker O, Flynn E, Underwood A, Condron R and Hogg PJ: Phosphoglycerate kinase acts in tumour angiogenesis as a disulphide reductase. Nature 408: 869-873, 2000.

15. Valenti MT, Bertoldo F, Dalle Carbonare L, Azzarello G, Zenari S, Zanatta M, Balducci E, Vinante O and Lo Cascio V: The effect of bisphosphonates on gene expression: GAPDH as a housekeeping or a new target gene? BMC Cancer 6: 49, 2006

16. Ullmannová $\mathrm{V}$ and Haskovec $\mathrm{C}$ : The use of housekeeping genes (HKG) as an internal control for the detection of gene expression by quantitative real-time RT-PCR. Folia Biol (Praha) 49: 211-216, 2003.

17. Pan SH, Chao YC, Hung PF, Chen HY, Yang SC, Chang YL, Wu CT, Chang CC, Wang WL, Chan WK, Wu YY, Che TF, Wang LK, Lin CY, Lee YC, Kuo ML, Lee CH, Chen JJ, Hong TM and Yang PC: The ability of LCRMP-1 to promote cancer invasion by enhancing filopodia formation is antagonized by CRMP-1. J Clin Invest 121: 3189-3205, 2011. 
18. Stelzl U, Worm U, Lalowski M, Haenig C, Brembeck FH, Goehler H, Stroedicke M, Zenkner M, Schoenherr A, Koeppen S, Timm J, MintzlaffS, Abraham C, Bock N, Kietzmann S, Goedde A, Toksöz E, Droege A, Krobitsch S, Korn B, Birchmeier W, Lehrach $\mathrm{H}$ and Wanker EE: A human protein-protein interaction network: a resource for annotating the proteome. Cell 122: 957-968, 2005.

19. Korherr C, Gille H, Schäfer R, Koenig-Hoffmann K, Dixelius J, Egland KA, Pastan I and Brinkmann U: Identification of proangiogenic genes and pathways by high-throughput functional genomics: TBK1 and the IRF3 pathway. Proc Natl Acad Sci USA 103: 4240-4245, 2006.

20. Czabanka M, Korherr C, Brinkmann U and Vajkoczy P: Influence of TBK-1 on tumor angiogenesis and microvascular inflammation. Front Biosci 13: 7243-7249, 2008.

21. Jia ZF, Huang Q, Kang CS, Yang WD, Wang GX, Yu SZ, Jiang H and Pu PY: Overexpression of septin 7 suppresses glioma cell growth. J Neurooncol 98: 329-340, 2010.

22. Endo Y, Sugiyama A, Li SA, Ohmori K, Ohata H, Yoshida Y, Shibuya M, Takei K, Enari M and Taya Y: Regulation of clathrinmediated endocytosis by p53. Genes Cells 13: 375-386, 2008

23. Enari M, Ohmori K, Kitabayashi I and Taya Y: Requirement of clathrin heavy chain for p53-mediated transcription. Genes Dev 20: 1087-1099, 2006.

24. Ofek P, Ben-Meir D, Kariv-Inbal Z, Oren M and Lavi S: Cell cycle regulation and $\mathrm{p} 53$ activation by protein phosphatase $2 \mathrm{C}$ alpha. J Biol Chem 278: 14299-14305, 2003.

25. Behrend L, Mohr A, Dick T and Zwacka RM: Manganese superoxide dismutase induces $\mathrm{p} 53$-dependent senescence in colorectal cancer cells. Mol Cell Biol 25: 7758-7769, 2005.

26. Shinbo Y, Taira T, Niki T, Iguchi-Ariga SM and Ariga H: DJ-1 restores p53 transcription activity inhibited by Topors/p53BP3 Int J Oncol 26: 641-648, 2005.

27. Grover A, Priyandoko D, Gao R, Shandilya A, Widodo N, Bisaria VS, Kaul SC, Wadhwa R and Sundar D: Withanone binds to mortalin and abrogates mortalin-p53 complex: Computational and experimental evidence. Int J Biochem Cell Biol 44: 496-504, 2012.

28. Wadhwa R, Yaguchi T, Hasan MK, Mitsui Y, Reddel RR and Kaul SC: Hsp70 family member, mot-2/mthsp70/GRP75, binds to the cytoplasmic sequestration domain of the p53 protein. Exp Cell Res 274: 246-253, 2002

29. Ueno M, Masutani H, Arai RJ, Yamauchi A, Hirota K, Sakai T, Inamoto T, Yamaoka Y, Yodoi J and Nikaido T: Thioredoxindependent redox regulation of p53-mediated p21 activation. J Biol Chem 274: 35809-35815, 1999.
30. Ueda S, Nakamura H, Masutani H, Sasada T, Yonehara S, Takabayashi A, Yamaoka Y and Yodoi J: Redox regulation of caspase-3(-like) protease activity: regulatory roles of thioredoxin and cytochrome c. J Immunol 161: 6689-6695, 1998.

31. Hsu HH, Cheng SF, Chen LM, Liu JY, Chu CH, Weng YJ, Li ZY, Lin CS, Lee SD, Kuo WW and Huang CY: Over-expressed estrogen receptor- $\alpha$ upregulates hTNF- $\alpha$ gene expression and downregulates $\beta$-catenin signaling activity to induce the apoptosis and inhibit proliferation of LoVo colon cancer cells. Mol Cell Biochem 289: 101-109, 2006.

32. Kouzmenko AP, Takeyama K, Ito S, Furutani T, Sawatsubashi S, Maki A, Suzuki E, Kawasaki Y, Akiyama T, Tabata T and Kato S: Wnt $/ \beta$-catenin and estrogen signaling converge in vivo. J Biol Chem 279: 40255-40258, 2004.

33. Won J, Kim DY, La M, Kim D, Meadows GG and Joe CO: Cleavage of 14-3-3 protein by caspase-3 facilitates bad interaction with Bcl-x(L) during apoptosis. J Biol Chem 278: 19347-19351, 2003.

34. Vousden KH and Prives C: P53 and prognosis: new insights and further complexity. Cell 120: 7-10, 2005.

35. Vousden KH and Lane DP: p53 in health and disease. Nat Rev Mol Cell Biol 8: 275-283, 2007.

36. Pietsch EC, Sykes SM, McMahon SB and Murphy ME: The p53 family and programmed cell death. Oncogene 27: 6507-6521, 2008.

37. Kruse JP and Gu W: Modes of p53 regulation. Cell 137: 609-622, 2009.

38. Plosker GL and Figgitt DP: Rituximab: a review of its use in non-Hodgkin's lymphoma and chronic lymphocytic leukaemia. Drugs 63: 803-843, 2003

39. Gavin AC, Bösche M, Krause R, Grandi P, Marzioch M, Bauer A, Schultz J, Rick JM, Michon AM, Cruciat CM, Remor M, Höfert C, Schelder M, Brajenovic M, Ruffner H, Merino A, Klein K, Hudak M, Dickson D, Rudi T, Gnau V, Bauch A, Bastuck S, Huhse B, Leutwein C, Heurtier MA, Copley RR, Edelmann A, Querfurth E, Rybin V, Drewes G, Raida M, Bouwmeester T, Bork P, Seraphin B, Kuster B, Neubauer G and Superti-Furga G: Functional organization of the yeast proteome by systematic analysis of protein complexes. Nature 415: 141-147, 2002. 